\title{
Isolation and characterization of Streptococcus spp. group B in Nile tilapias (Oreochromis niloticus) reared in hapas nets and earth nurseries in the northern region of Parana State, Brazil
}

\author{
Isolamento e caracterização de Streptococcus spp. do grupo B em tilápias do Nilo \\ (Oreochromis niloticus) criadas em tanques rede e em viveiros de terra \\ na região norte do Estado do Paraná, Brasil \\ Rogério Salvador $^{1}$ Ernst Eckehardt Muller $^{2}$ Julio César de Freitas $^{3}$ \\ Julio Hermann Leonhadt ${ }^{4}$ Lucienne Garcia Pretto-Giordano ${ }^{5}$ Juliana Alves Dias $^{6}$
}

\begin{abstract}
The objective of this study was to isolate and characterize Streptococcus spp. in Nile tilapias (Oreochromis niloticus) reared in net-pens and earth nurseries. Eight intensive tilapia-rearing farms were investigated in north Paraná, Brazil from April $1^{\text {st }} 2001$ to April 30 ${ }^{\text {th }}$ 2002. The fish were reared in a system of hapas nets on four farms and in earth nurseries on other four farms. A total of 370 samples were analyzed of material collected from 120 fish (brain, liver, kidney, skin scrapes, ascites liquid and eye) that were sown on BHI agar (Brain Heart Infusion) supplemented with $1 \%$ yeast extract and sheep blood. Streptococcus spp. was isolated in 36 of the samples (18 brain, eight liver, eight kidney and two ascites liquid) from 25 fish. Streptococci were isolated in both systems, almost in the same proportion. First the streptococci were characterized by the catalase and esculin test, growth in methylene blue and sodium chloride at 6.5\%. They were classified in groups by the Slidex Strepto-Kit (BioMerieux, France). The phenotypic characteristics were determined by the Api 20 Strep microtest system (BioMerieux, France). The 36 Streptococcus spp. samples did not present hemolysis and were classified as Lancefield group B. Further 16 samples were identified as Streptococcus agalactiae and 20 were not identified by the Api 20 Strep, but presented the same biochemical profile described for the reference strain of Streptococcus difficile (ND-2-22).
\end{abstract}

Key words: pisciculture, streptococci, infection, bacteriology. RESUMO

O objetivo deste trabalho foi isolar e caracterizar o Streptococcus spp. em tilápias do Nilo (Oreochromis niloticus) cultivadas em sistema de tanque rede e em viveiros de terra. Oito propriedades de criação intensiva foram estudadas de 1 de abril de 2001 a 30 de abril de 2002. Em quatro propriedades, os peixes eram cultivados em sistema de tanque rede e em quatro em sistema de tanque terra. Ao todo foram analisadas 370 amostras de material colhido de 120 peixes (encéfalo, fígado, rim, raspado de pele, líquido ascítico e olho) que foram semeadas em ágar BHI (Brain Heart Infusion) contendo sangue ovino e extrato de levedura. Streptococcus spp. foi isolado de 36 amostras (18 amostras de encéfalo, oito de fígado, oito de rim e duas de líquido ascítico), provenientes de 25 peixes. Estreptococos foram isolados, quase na mesma proporção, nos dois sistemas de cultivo. Inicialmente os estreptococos foram caracterizados pela prova da catalase e esculina, crescimento em azul de metileno e NaCl a 6.5\%. A classificação em grupos foi efetuada pelo Slidex Strepto-Kit (BioMerieux, França). As características fenotípicas foram determinadas pelo sistema de microtestes API 20 Strep (BioMerieux, França). As 36 amostras de estreptococos não apresentaram hemólise e foram classificadas no grupo B de Lancefield. Dessas, 16 amostras

${ }^{1}$ Curso de Medicina Veterinária da Faculdade Luiz Meneghel, Bandeirantes, Paraná, Brasil.

${ }^{2}$ Departamento de Medicina Veterinária Preventiva, Centro de Ciências Agrárias (CCA), UEL, Londrina, Paraná.

${ }_{3}^{3}$ Departamento de Medicina Veterinária Preventiva, Centro de Ciências Agrárias (CCA), UEL, Londrina, Paraná. Author for correspondence: Dr. Julio César de Freitas,Rodovia Celso Garcia Cid, (PR445), Km 380, CP6001, 86051-990. Tel: (43)33714765; Fax: (43)3371-4714. E-mail: freitasj@uel.br

${ }^{4}$ Departamento de Ciências Fisiológicas, Centro de Ciências Biológicas (CCB), UEL, Londrina, Paraná.

${ }_{5}^{5}$ Laboratório de Microbiologia Veterinária, Departamento de Medicina Veterinária Preventiva, CCA, UEL, Londrina, Paraná.

${ }^{6}$ Programa de Pós-graduação em Ciência Animal, CCA, UEL 
foram identificadas como Streptococcus agalactiae e 20 não foram caracterizadas pelo API 20 Strep, mas apresentaram o mesmo perfil bioquímico descrito para a cepa de referência de Streptococcus difficile (ND-2-22). A ausência de hemólise, classificação no grupo $B$ e o perfil bioquímico sugerem que estes estreptococos podem pertencer à espécie Styreptococcus difficile.

Palavras-chave: piscicultura, estreptocococos, infecção, bacteriologia.

\section{INTRODUCTION}

Fish farming is one of the fastest growing segments of animal production in the world (PEREZ, 1999). The world production of tilapia (Oreochromis spp.) has grown expressively since 1984 and occupies an outstanding position among the species reared in fresh water (ALCESTE \& JORY, 2000).

In Brazil, fish farming is in the phases of consolidation and expansion (CHAMMAS, 1997). Until 1979 , the annual production of reared tilapias was not more than five thousand tons but currently it is 30 to 40 thousand tons annually (STICKNEY, 2001). Paraná state is the largest tilapia producer in the country, followed by São Paulo and Santa Catarina states.

The growth of fish farming in Brazil has been disorganized and characterized by high mortality rate, mainly because of bacterial diseases and low hygienic and sanitary quality (PEREZ, 1999). Among the bacterial diseases, septicemia by Streptococcus spp. is the largest problem in intensive tilapia rearing systems throughout the world (SURESH, 1998).

Several species of Streptococcus spp. can be involved in fish infections. WU (1970) reported the first isolation of Streptococcus spp. in tilapias and since then this pathogen has been blamed for high losses, especially in Japan (KITAO et al., 1981), Israel (HUBERT, 1989), Saudi Arabia (AL-HARB, 1994) and recently in the United States and Central America (PLUMB, 1997).

Streptococcus iniae, described for the first time by PIER \& MADIN (1976), has been considered as the important pathogen in tilapias (PERERA et al., 1997; DODSON et al., 1999; SHOEMACKER et al., 2001). Other species are described as disease causers: Streptococcus faecium (KUSUDA et al., 1976; MINAMI, 1979), Streptococcus agalactiae (KUSUDA \& KOMATSU, 1978), Streptococcus equi, Streptococcus equisimilis, Streptococcus pyogenes, Streptococcus zooepidemicus (UGAJIN, 1981) and Streptococcus difficile and Streptococcus shilloi (ELDAR et al., 1994). BUNCH \& BEJERANO (1997) studied the infection of fish by $S$. difficile and observed greater infection occurrence in fish cultivated in waters with high temperatures, showing the importance of $\boldsymbol{S}$. difficile in locations with higher temperatures. The objective of this study was the isolation and characterization of Streptococcus spp. isolates of fish that presented clinical signs of bacterial infections in their fattening stage.

\section{MATERIAL AND METHODS}

Eight intensive tilapia rearing farms were studied in the Northern region of Paraná state, from April $1^{\text {st }} 2001$ to April $30^{\text {th }} 2002$. On four farms, the fish were reared in a system of hapas nets and on the other four, in earth nurseries. Fish presenting signs such as darkened skin, lethargy, erratic and circular swimming were captured and placed in plastic bags containing water from the location itself and oxygen under pressure, transported to the Microbiology and Infectious Diseases Laboratory at the Department of Preventive Veterinary Medicine at Londrina State University (UEL), and examined immediately. One hundred and twenty fish were collected, totaling 370 samples of biological materials, namely 120 brain, 120 liver, 120 kidney samples, six skin scrapings, two ascite liquids and two eyes.

In the laboratory, the fish were submitted to external physical examination and necropsy. Kidney, brain and liver samples were collected aseptically from all the animals along with other biological materials (skin scrapings, ascites liquid and eye) that presented macroscopic alteration. They were sown on plates containing BHI agar, supplemented with $1 \%$ yeast extract (BUNCH \& BEJERANO, 1997) and sheep blood, and incubated at $30^{\circ} \mathrm{C}$ in aerophile atmosphere for five days.

The microorganisms were identified according to their cultural, morphological, tintorial and biochemical characteristics (HOLT et al., 1994). The streptococci that had been characterized previously by the catalase and esculin test, growth test in methylene blue and sodium chloride at $6.5 \%$, were later classified in groups by Slidex Strepto-Kit (BioMerieux, France). The species were identified in 36 samples by their phenotypic characteristics, determined by the Api 20 Strep Microtest (BioMerieux, France) after incubation at $30^{\circ} \mathrm{C}$ and readings at four and 24 hours.

\section{RESULTS AND DISCUSSION}

The main clinical signs detected in the fish were lethargy, loss of appetite, spine displacement, uni or bilateral exophthalmia, abdominal extension and 
erratic and circular swimming. Hemorrhagic lesions were observed on the skin, ascites, hepatomegalia and splenomegalia and pale liver were observed at the necrospy. Of the 120 fish researched, 25 (20.83\%) presented Streptococcus spp. Growth. Streptococci were isolated in both systems, almost in the same proportion. Of the 77 biological materials from the 25 fish, Streptococcus spp. were isolated in 36 (46.75\%) (18 samples of brain, eight liver, eight kidney and two ascitic liquid samples). The predominance of the isolation from the brain indicates the need for the routine bacteriological examination in this organ, because in fish with clinical suspicion of infection by Streptococcus spp. the clinical neurological signs resulting from meningoencephalitis can be observed. The relatively low isolation indexes may indicate little sensitivity in the bacterial culture, the participation of other etiological agents or further, low specificity of the clinical signs in the Streptococcus spp. infection in tilapias. Low correlation between the clinical signs and the etiological agents was described by ELDAR et al. (1995) and PLUMB (1999).

In the BHI agar the Streptococcus spp. colonies were gray colored, translucent, circular, slightly convex, pin head and not hemolytic. All strains presented negative results in the catalase and esculin tests, growth in sodium chloride at $6.5 \%$ and methylene blue. The 36 Streptococcus spp. samples submitted to the Slidex Strepto-Kit test presented the antigen carbohydrate belonging to the Lancefield group B and in the Api 20 Strep two phenotypical homogeneous groups were identified. Sixteen samples were identified as $\boldsymbol{S}$. agalactiae. The twenty remaining samples presented the same biochemical profile, but were not identified by the system used. This profile corresponded to that described by ELDAR et al. (1994) and VANDAMME et al. (1997) for the reference strain of Streptococcus difficile (ND-2-22) (Table 1).

According to VANDAMME et al. (1997) S. difficile belongs to group $\mathrm{B}$ type $\mathrm{Ib}$ and presents total cell protein indistinguishable from $S$. agalactiae, but the biochemical profile of $\boldsymbol{S}$. difficile is different from S. agalactiae, but similar to that observed in other group B, Ib type Streptococcus spp. isolated in fish. BERRIDGE et al. (2001) also detected a significant homology $(97.7 \%)$ in the sequence of nucleic acids between the 16S-23S rDNA, the S. difficile and S. agalactiae.

S. difficile was described for the first time in Israel as the cause of septicemia and meningoencephalitis in reared tilapias and trout (Oncorrhyncus mykiss) (ELDAR et al., 1994). S. difficile is the most prevalent species in intensive tilapia rearing in Israel and is responsible for approximately $30 \%$ of the mortality on the farms studied (ELDAR et al., 1995).

Streptococcus spp. with beta hemolise and $S$. iniae biochemical profile were not identified. This species has been described as one of the most frequent in Streptococcus spp. infections in tilapias (PERERA \& JOHNSON, 1994; ELDAR et al., 1995; BOWSER et al., 1998; EVANS et al., 2000). BUNCH \& BEJERANO (1997) in a study carried out in Israel observed that $\boldsymbol{S}$. iniae predominated in tilapias reared at low temperatures $\left(15^{\circ} \mathrm{C}\right.$ and $\left.16^{\circ} \mathrm{C}\right) \mathrm{S}$. difficile predominated whereas in rearing at higher temperatures $\left(26^{\circ} \mathrm{C}\right.$ to $\left.28^{\circ} \mathrm{C}\right)$. This fact might explain the non-isolation of $\boldsymbol{S}$. iniae in this study, as the mean water temperature on the farms studied oscillated between $24^{\circ} \mathrm{C}$ and $26^{\circ} \mathrm{C}$ and at the same time reinforces

Table 1 - Comparison among sugar use characteristics and the enzymatic profile of $\boldsymbol{S}$. difficile obtained by ELDAR et al. (1994) and VANDAMME et al. (1997) and 20 group B Streptococcus spp. isolated and submitted to Api 20 Strept (BioMerieux, France).

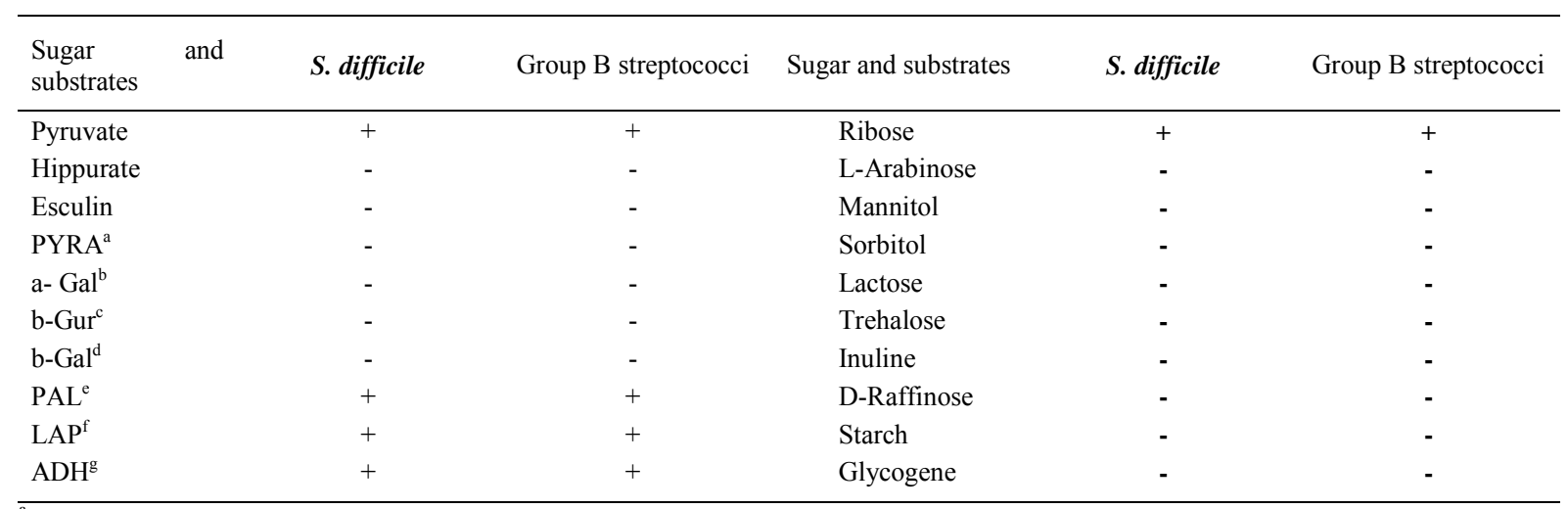

Pyrrolidonylarylamidase, ${ }^{\mathrm{b}} \alpha$-galactosidase, ${ }^{\mathrm{c}} \beta$-glucuronidase, ${ }^{\mathrm{d}} \beta$ - galactosidase, ${ }^{\mathrm{e}}$ Alkaline phosphatase, ${ }^{\mathrm{f}}$ Leucine arylamidase, ${ }^{\mathrm{g}}$ Arginine dihydrolase. 
the possible involvement of $\boldsymbol{S}$. difficile in the tilapia infections on the farms studied.

Although there are no reports involving $\boldsymbol{S}$. difficile in diseases in man, its taxonomic relationship with $\boldsymbol{S}$. agalactiae and $\boldsymbol{S}$. iniae should alert the health authorities to this possibility (BERRIDGE et al., 2001) because other non hemolytic Streptococcus spp. from group B have been isolated in humans (ELLIOT et al., 1990).

\section{CONCLUSION}

The isolation of non hemolytic Streptococcus spp. from group B is strong evidence of the participation of these agents in the etiology of the septicemias and meningoencephalites in tilapias reared in the north of Paraná state, Brazil.

\section{ACKNOWLEDGEMENTS}

Parte da dissertação apresentada pelo primeiro autor ao Programa de Pós-graduação em Ciência Animal da Universidade Estadual de Londrina (UEL) para obtenção do título de Mestre.

\section{REFERENCES}

ALCESTE, C.C.; JORY, D.E. Best tilapia strains? Aquaculture Magazine, v.25, p.80-84, 2000.

AL-HARB, A.H. First isolation of Streptococcus sp. from hybrid tilapia (Oreochromus niloticus x Oreochromus aureus) in Saudi Arabia. Aquaculture, v.128, p.263-271, 1994

BERRIDGE, B.R. et al. Streptococcus agalactiae and Streptococcus difficile 16S-23S intergenic rDNA: genetic homogeneity and species-specific PCR. Veterinary Microbiology, v.78, p.165-173, 2001.

BOWSER, P.R. et al. Streptococcus iniae infection of Oreochromis niloticus in a recirculation production facility. Journal of the World Aquaculture Society, v.29, p.335-339, 1998.

BUNCH, E.C.; BEJERANO, Y. The effect of environmental factors on the susceptibility of hibrid tilapia Oreochromis niloticus x Oreochromis aureus to streptococcosis. Israeli Journal of Aquaculture, v.49, p.67-76, 1997.

CHAMMAS, M. Panorama da aquicultura brasileira: a região Sul. Anais Workshop Internacional de Aqüicultura, v.1, p.56-61, 1997.

DODSON, S.V. et al. Biochemical and molecular typing of Streptococcus iniae isolated from fish and human cases. Journal of Fish Disease, v.22, p.331-336, 1999

ELDAR, A. et al. Streptococcus shiloi and Streptococcus difficile: two new streptococcal species causing a meningoencephalitis in fish. Current Microbiology, v.28, p.139-143, 1994
ELDAR, A. et al. Streptococcus shilloi, the name for an agent causing septicemic infection in fish, is a junior synonym of Streptococcus iniae. International Journal Systematic Bacteriology, v.45, p.840-842, 1995.

ELLIOT, J.A. et al. Whole-cell protein patterns of nonhemolytic group B, type Ib streptococci isolated from humans, mice, cattle, frogs, and fish. Journal Clinical Microbiology, v.28, p.628-630, 1990.

EVANS, J.J. et al. Experimental Streptococcus iniae infection of hybrid striped bass (Morone chrysops X Morone saxatilis) and tilapia (Oreochromis niloticus) by nares inoculation. Aquaculture, v.189, p.197-210, 2000.

HOLT, J.G. et al. Bergey's manual of determinative bacteriology. 9.ed. Philadelphia: Williams \& Wilkins, 1994. $787 \mathrm{p}$.

HUBERT, R.M. Bacterial diseases in warm water aquaculture. In: SHILO, M.; SARIG S. (Ed). Fish culture in warm water systens. Problems and trends. Florida: Boca Raton, 1989. p. 194-197.

KITAO, T. et al. Epizootic caused by beta-haemolytic Streptococcus species in cultured freshwater fish. Fish Pathology, v.15, p.301-307, 1981.

KUSUDA, R. et al. A new pathogenic bacterium belonging to the genus Streptococcus, isolated from an epizootic of cultured yellowtail. Bulletin of the Japonese Society of Scientific Fisheries, v.42, p.1345-1352, 1976.

KUSUDA, R.; KOMATSU, I. A comparative study of fish pathogenic Streptococcus isolated from saltwater and freshwater fishes. Bulletin of the Japanese Society of Scientific Fisheries, v.44, p.1073-1078, 1978.

MINAMI, T. A beta-hemolitic Streptococcus isolated from cultured yellowtail. Fish Pathology, v.14, p.15-19, 1979.

PERERA, R.P.; JOHNSON, S.K. Streptococcus iniae associated with mortality of Tilapia nilotica x Tilapia aurea hybrids. Journal of Aquatic Animal Health, v.6, p.335-340, 1994.

PERERA, R.P. et al. Epizootiological aspects of Streptococcus iniae affecting tilapia in Texas. Aquaculture, v.152, p.2533, 1997.

PEREZ, A.C. Empreendimentos piscícolas e o médico veterinário. Revista de Educação Continuada do CRMVSP, v.2, p.43-65, 1999

PIER, G.B.; MADIN, S.H. Streptococcus iniae sp. nov a beta hemolytic streptococcus isolated from a Amazon freshwater dolphin, Inia geoffrensis. International Journal Systematic Bacteriology, v.26, p.545-553, 1976.

PLUMB, J.A. Infections diseases of tilapia. In: COSTAPIERCE, B.A.; RAKOCY, J.E. Tilapia aquaculture in the Americas. Baton Rouge, Louisiana: World Aquaculture Society, 1997. V.1, p.212-218.

PLUMB, J.A. Health: maintenance and principal microbial diseases of cultured fishes. Ames: Iowa State University, 1999. 328p. 
STICKNEY, R.R. Tilapia Update 2000. World Aquaculture, v.32, p.4-68, 2001.

SHOEMACKER, C.A. et al. Prevalence of Streptococcus iniae in tilapia, hybrid striped bass, and channel catfish on commercial fish farms in the United States. American Journal Veterinary Research, v.62, n.174-177, 2001 .

SURESH, A.V. Tilapia update 1998. World Aquaculture , v.30, p.8-68, 1998
UGAJIN, M. Studies on Streptococcus sp as a causative agent of an epizootic among the cultured ayu (Plecoglossus altivelis) in Tochigi Prefecture, Japan, 1980. Fish Pathology, v.16, p.119-127, 1981.

VANDAMME, P. et al. Streptococcus difficile is a nonhemolytic Group B, tipe Ib Streptococcus. International Journal Systematic Bacteriology, v.47, p.81-85, 1997.

WU, S.Y. New bacterial disease of tilapia. Fish Culture Bulletin, v.23, p.3-40, 1970. 